\title{
CRIAÇÃo dE ÁREAS DE RISCO: OS PROBLEMAS COM ALAGAMENTOS NO DISTRITO DE RIO VERMELHO, FLORIANÓPOLIS / SC
}

\author{
Edna Lindaura Luiz ${ }^{1}$ \\ Larissa Anjos Santos ${ }^{2}$ \\ João Paulo Oliveira da Rosa ${ }^{3}$
}

Resumo: O presente trabalho trata da criação de áreas de risco a alagamentos no Distrito de Rio Vermelho/SC. Este Distrito possui diferentes tipos de áreas úmidas, porém aquelas localizadas no interior do terraço marinho foram urbanizadas porque nem sempre estão úmidas ao longo do tempo. Moradores antigos sabiam que estas áreas alagavam em episódios de chuvas excepcionais, contudo, são pessoas migrantes que compraram terrenos ali. $O$ parcelamento do solo irregular, sem planejamento e fiscalização do poder público associado ao desconhecimento da dinâmica natural do lugar criaram áreas de risco a alagamento. Medidas estruturais de drenagem não conseguirão acabar com os alagamentos por completo, por isso devem ser implantadas também medidas não-estruturais que diminuam a vulnerabilidade dos moradores.

Palavras-chave: Fenômenos de alagamento. Áreas de risco. Terraço marinho arenoso. Ocupação irregular. Características do meio físico.

\section{CREATION OF RISK AREAS: THE PROBLEMS WITH FLOODING IN THE RIO VERMELHO DISTRICT, FLORIANÓPOLIS / SC}

Abstract: This paper discusses the creation of flood risk areas in the Rio Vermelho District / SC. This district has different types of wetlands, but those places located on the sandy marine terrace were the subject of intense human occupation because they are not always wet over time. Former residents knew that these areas flooded in episodes of exceptional rainfall, however, are migrant people who bought land there. The irregular soil parceling, without planning and inspection of the public power associated to the ignorance of the natural dynamics of the place, created areas of risk to flood. Structural measures of drainage will be unable to stop the flooding completely, so should also be implemented non-structural measures to reduce the vulnerability of the residents.

Keywords: Flooding. Risk areas. Sandy marine terrace. Irregular settlements. Physical environment characteristics.

\section{CREACIÓN DE ÁREAS DE RIESGO: LOS PROBLEMAS CON ALAGAMIENTOS EN EL DISTRITO DE RIO VERMELHO, FLORIANÓPOLIS / SC}

Resumen: El presente trabajo trata de la creación de áreas de riesgo a alagamientos en el Distrito de Rio Vermelho / SC. Este Distrito presenta diferentes tipos de áreas húmedas, pero las ubicadas en el interior de la terraza marina se han

\footnotetext{
${ }^{1}$ Universidade do Estado de Santa Catarina, Departamento de Geografia, Florianópolis/SC, Brasil, elinluiz@uol.com.br, https://orcid.org/0000-0002-1825-0097

${ }^{2}$ Universidade do Estado de Santa Catarina, Programa de Pós-Graduação em Educação,

Florianópolis/SC, Brasil, lariiianjos@gmail.com, https://orcid.org/0000-0002-1825-0097

${ }^{3}$ Universidade do Estado de Santa Catarina, Curso de Geografia Bacharelado, Florianópolis/SC, Brasil, joaopauloor1996@gmail.com, https://orcid.org/0000-0002-1825-0097
} 
urbanizado porque no siempre están húmedas a lo largo del tiempo. Moradores antiguos sabían que estas áreas llenan de agua en episodios de lluvias excepcionales, sin embargo, son personas migrantes que compraron terrenos allí. El parcelamiento del suelo irregular, sin planificación y fiscalización del poder público asociado al desconocimiento de la dinámica natural del lugar, crearon áreas de riesgo a alagamientos. Las medidas estructurales de drenaje no lograrán acabar con los alagamientos por completo, por lo que deben implantarse también medidas no estructurales que disminuyan la vulnerabilidad de los habitantes.

Palabras clave: Fenómenos de alagamento. Áreas de riesgo. Terraza marino arenoso. Asentamientos humanos irregulares. Características del medio físico.

\section{Introdução}

O ambiente natural onde o ser humano vive e constrói suas comunidades apresenta funcionamento de acordo com uma dinâmica própria, diferente daquela da sociedade humana. $O$ modo de produção capitalista é baseado na geração do lucro e aumento da produtividade e isto está sendo alcançado com cada vez maior eficiência tecnológica. Esta é a lógica da superestrutura da sociedade atual. Diante disso, perdeu-se a convivência mais próxima e adaptada às características da natureza (meio físico e meio biológico) nas sociedades mais modernas e engendradas no modo capitalista. Em muitos lugares já não há mais íntima dependência do meio natural para a sobrevivência humana, especialmente no espaço urbanizado, o qual se expandiu muito nos últimos anos.

Contudo, não se pode afirmar que a sociedade humana prescinde do meio natural, pois ele ainda é o substrato para as estruturas e atividades humanas e, um exemplo disso, são as áreas de risco a fenômenos perigosos da dinâmica natural. Tricart (1965 e 1977) explica que há ambientes do meio físico fortemente instáveis do ponto de vista de seu funcionamento, ou seja, há grande atuação dos processos da dinâmica externa e/ou interna da Terra, o que ocasiona mudança de formas de relevo, de solos, de ecossistemas em curtos espaços de tempo. Estes se configuram em locais de morfogênese.

Um destes locais é o de fundo de vale com planície, onde são frequentes as cheias do rio, levando a fenômenos como inundação, assoreamento, migração lateral do leito, erosão de margem. A dinâmica do cenário fundo de vale será modificada em função do regime de chuvas ou de degelo na bacia de drenagem e isso faz parte da natureza deste ambiente, ele está sempre mudando. Em comunidades humanas mais dependentes para sua sobrevivência do meio natural, estes locais são muito bem conhecidos e evitados ou até são utilizados para certos usos adaptados ao seu funcionamento. Este tipo de conhecimento era passado de 
geração a geração e não havia grandes perdas ou danos quando as transformações ocorriam.

Com certos locais deixando de ser periferia no sistema capitalista e entrando de forma mais direta no circuito de produção, há maior intensidade da ocupação humana nos espaços naturais, com uso mais massivo da tecnologia na transformação dos ambientes. Isto também amplia os espaços urbanos em detrimento dos antigos e atrasados espaços rurais. Este foi o caso do município de Florianópolis, que na década de 1970, a partir da construção da rodovia BR 101 e da ponte Colombo Salles e de outras obras e iniciativas, começou a se integrar de forma mais efetiva ao mundo capitalista regional e nacional. O município deixou de ser eminentemente rural, com pequena produção familiar de subsistência basicamente para se transformar em polo turístico, tecnológico e de serviços no século XXI. Esta transformação econômica foi seguida de grande aumento populacional pela chegada de migrantes, com consequente avanço das áreas urbanizadas.

A demanda por moradias cresceu muito no município em pouco tempo, especialmente após os anos 1990. As encostas das elevações cristalinas dos bairros próximos ao centro da cidade começaram a ser urbanizadas de forma precária, criando muitos problemas aos moradores, pois estas eram áreas que estavam em equilíbrio apenas devido à cobertura vegetal de mata atlântica em regeneração. A retirada da vegetação, a abertura de arruamentos perpendiculares à encosta e a realização de cortes ampliaram a atuação dos processos do meio físico perigosos (enxurradas, deslizamentos, quedas de blocos rochosos, fluxos torrenciais em rios), como foi observado por Luiz (1992) nas encostas do bairro Saco Grande. Desta forma, foram criadas áreas de risco por dois motivos: primeiro pela amplificação da atuação dos processos naturais do meio físico, ou seja, foi aumentada a suscetibilidade do lugar a eventos perigosos; e segundo, porque como observou Luiz (1992), a população de imigrantes que foram ocupar as encostas desconheciam completamente a estrutura e a dinâmica do meio físico de onde se estabeleceram, o que os deixava mais vulneráveis aos processos naturais.

Geralmente, as áreas mais instáveis são ocupadas por pessoas de menor renda, pois são as menos valorizadas, justamente a população mais vulnerável aos eventos perigosos. Atualmente, no município de Florianópolis, as terras mais baratas estão longe do centro da cidade, como é o caso daquelas situadas no Distrito de Rio Vermelho, na região nordeste. Este é um dos últimos espaços do município a deixar 
de ser rural e se transformar em urbano em função da procura por moradias e a instalação de comércio e serviços para atender as demandas do aumento populacional.

O que ocorre é que no Distrito do Rio Vermelho há áreas que sempre sofreram com alagamentos em momentos de chuvas intensas e/ou continuadas e que agora estão sendo urbanizadas. Diante disso, o objetivo do presente trabalho é discutir a dinâmica natural destas áreas e as mudanças no seu processo de ocupação humana, as quais levaram a transformação destes locais em áreas de risco no Distrito. Um breve resumo deste trabalho foi apresentado no I Congresso Brasileiro de Redução de Riscos de Desastres realizado em Curitiba em 2016.

As áreas de risco são aquelas em que existe ameaças (ou perigos) que ao se concretizarem provocam perdas e danos para uma população instalada no local e que é vulnerável a elas (CERRI e AMARAL, 1998; KOBYAMA et al., 2006; PALACIOS et al., 2005, entre outros). Para Brasil (2007, p. 26), área de risco é: "Área passível de ser atingida por fenômenos ou processos naturais e/ou induzidos que causem efeito adverso. As pessoas que habitam essas áreas estão sujeitas a danos a integridade física, perdas materiais e patrimoniais".

O perigo (ou ameaça) corresponde a um fenômeno, processo ou substância com potencial para causar perdas e danos a propriedade e a infraestrutura, perdas de serviços públicos, mortes e/ou lesões, transtornos sociais e econômicos (BRASIL, 2007, NAÇÕES UNIDAS, 2009). A Estratégia para redução de desastres das Nações Unidas (NAÇÕES UNIDAS, 2009) coloca que há vários tipos de perigos, incluindo aí os de natureza geológica e hidrometeorológica. Os alagamentos e inundações são fenômenos hidrometeorológicos da dinâmica natural no Distrito de Rio vermelho que se transformam em perigo por causa da ocupação humana inadequada em suas áreas de ocorrência.

A vulnerabilidade surge quando as áreas de atuação de fenômenos ou processos que podem ser perigosos são ocupadas pelo ser humano. Desta forma, vulnerabilidade é o quanto um determinado sistema, comunidade ou bem pode ser atingindo pela concretização de um perigo (PALACIOS et al., 2005; BRASIL, 2007; NAÇÕES UNIDAS, 2009). Ela expressa o grau de perdas materiais, de vidas e socioambientais envolvidas.

Algumas vezes, a ocupação humana pode se adaptar a ocorrência de fenômenos perigosos e por isso se tornam menos vulneráveis, contudo há casos em que é impossível conviver com os perigos. A vulnerabilidade tem diferentes 
dimensões, tais como a econômica, a social, a cultural, a política e a educacional segundo Palacios et al. (2005). Estes autores colocam que quanto menos as pessoas sabem sobre os perigos ou ameaças, mais vulneráveis elas são a eles. Como explica White (1945) sobre os fenômenos de cheias dos rios nos Estados Unidos, estes se tornavam perigosos porque havia ocupação humana nas planícies fluviais e as pessoas não conheciam a dinâmica dos rios e assim se tornavam vulneráveis por não saber conviver com essa dinâmica

\section{Área de estudo}

O Distrito de Rio Vermelho está situado aproximadamente entre as coordenadas UTM de $752.349 \mathrm{~m}$ e $759.089 \mathrm{~m}$ E e de $6.960 .509 \mathrm{~m}$ e $6.953 .627 \mathrm{~m} \mathrm{~N}$, fuso 22 Sul, na parte nordeste da ilha de Santa Catarina. Esta ilha abriga grande parte do município de Florianópolis/SC e ela se encontra em latitude subtropical, sendo submetida a massas de ar de origem tropical e polar, com temperaturas médias mensais variando durante o ano entre $16,3^{\circ} \mathrm{C}$ no mês de julho a $24,6^{\circ} \mathrm{C}$ em fevereiro, segundo dados estação climatológica de São José (mantida pelo Instituto Nacional de Meteorologia). As chuvas são bem distribuídas, mas diminuem um pouco no inverno, com médias mensais de $82,6 \mathrm{~mm}$ em julho e $197 \mathrm{~mm}$ em janeiro (dados da estação climatológica de São José). Contudo, em qualquer momento do ano podem ocorrer precipitações excepcionais em ternos de intensidade e duração por causa da atuação de sistemas atmosféricos específicos, tais como frentes frias, vórtices ciclônicos, convecção tropical, cavados, entre outros (MONTEIRO; MENDONÇA, 2014).

De acordo com levantamento de campo e mapeamento geomorfológico realizado por Luiz e Lamas (2017) (Figura 1), o relevo da área de estudo apresenta compartimentos variados esculpidos sobre rochas cristalinas e sobre sedimentos quaternários de diferentes ambientes de deposição. Na porção oeste do Distrito, há elevações cristalinas de morros e montanhas modeladas sobre granitos e diques básicos. No sopé destas elevações, há superfícies rampeadas constituídas por depósitos colúvio-aluviais. Estas rampas fazem a transição entre as elevações e a planície do rio João Gualberto, sendo que esta última apresenta sedimentos marinhos e continentais retrabalhados pelos rios. Nesta planície, o lençol freático está muito próximo da superfície, formando diversas áreas úmidas ao longo de sua extensão. 


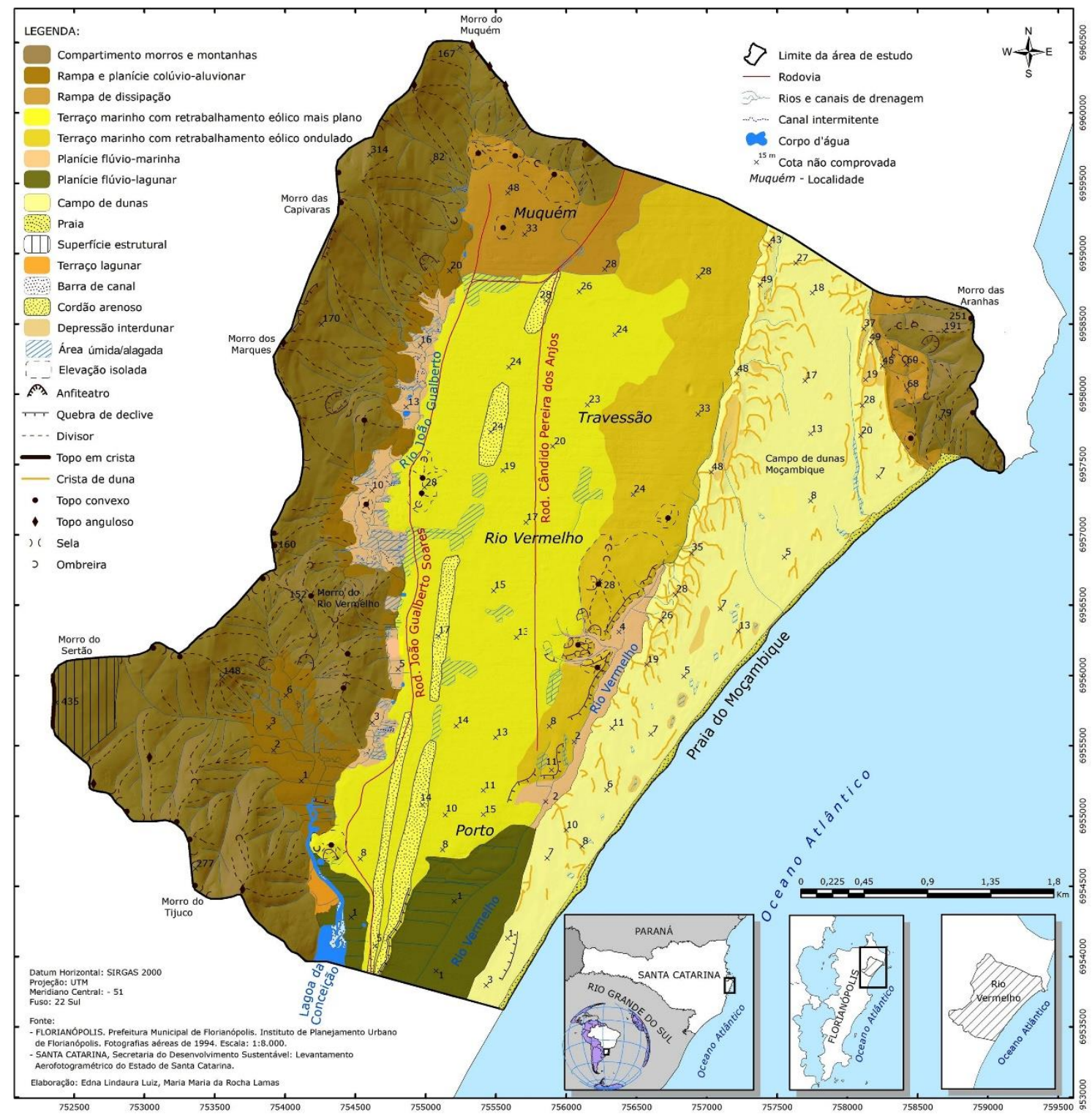

Figura 1. Mapa geomorfológico do Rio Vermelho, Florianópolis/SC.

Fonte: adaptado de Luiz e Lamas (2017)

A leste da planície do rio João Gualberto, se encontra um terraço arenoso marinho retrabalhado pelo vento com idade pleistocênica. As altitudes neste terraço diminuem de norte para sul, ou seja, em direção à Lagoa da Conceição, que se encontra ao nível do mar. No interior deste terraço, há elevações isoladas, talvez antigas formas de dunas fossilizadas e também áreas úmidas, onde é possível verificar o afloramento do lençol freático. Em direção ao oceano atlântico, a leste, o terraço marinho dá lugar a uma extensa área alongada de banhado que configura a planície do rio Vermelho, o qual tem este nome por causa da cor castanhaavermelhada de suas águas, ricas em substâncias orgânicas e ferro, resultado da má drenagem na área. 
Os terrenos baixos do banhado fazem limite com o campo de dunas de Moçambique a leste, o qual apresenta diferentes feições, como dunas transversais e longitudinais e depressões inter-dunares que representam áreas de deflação. As depressões inter-dunares também se configuram como áreas úmidas, mas a maioria delas muda de lugar em função da dinâmica do vento. O limite mais a leste da área de estudo é a praia de Moçambique, a mais extensa praia da ilha de Santa Catarina.

A nordeste, se encontra o maciço cristalino das Aranhas com elevações de morros e montanhas, sendo que seu limite com a praia de Moçambique e com o campo de dunas se faz por rampas de dissipação, que nada mais são do que dunas acavaladas nas elevações cristalinas contaminadas com sedimentos que caem das encostas. Ao sul, ocorrem planícies flúvio-lagunares, resultado da colmatação de antigos corpos lagunares. Estas planícies apresentam o lençol freático próximo da superfície e tendem a sofrer alagamentos com as chuvas.

Nas elevações cristalinas, os solos e o clima úmido permitem 0 desenvolvimento de floresta ombrófila densa e nos solos derivados dos sedimentos arenosos marinhos e eólicos, a vegetação nativa é a de restinga com diferentes fisionomias (de porte herbáceo até arbustivo e arbóreo). Sobre o terraço marinho é raro existir a vegetação de restinga primária ou em estágio avançado de regeneração por causa da intensa ocupação humana.

O Distrito do Rio Vermelho foi ocupado por portugueses açorianos em meados do século XVIII. Eles estabelecerem-se em pequenas propriedades, cultivando produtos de subsistência e criando gado, especialmente nos terrenos do terraço marinho e da planície do rio João Gualberto, com a vegetação nativa destes lugares retirada. Dois produtos passaram a ser plantados para venda, o café e a mandioca, sendo que o primeiro perdeu importância depois da crise econômica de 1929. A transformação da mandioca em farinha em engenhos permaneceu como atividade significativa na área até a segunda metade do século XX. Nesta época, o local também tinha expressiva produção de leite.

Na década de 1990, as antigas propriedades rurais começaram a ser loteadas em virtude da procura por terrenos mais baratos. Foram implantados muitos loteamentos irregulares de acordo com observações in loco na época e pesquisas realizadas no Instituto de Planejamento de Florianópolis (IPUF), pois o plano diretor do município ainda considerava esta área como rural e, por isso, o parcelamento de terras em lotes não era permitido. Inclusive, a área dos lotes era menor do que 
exigia a legislação daquele período e os arruamentos foram abertos na forma de servidões sem passeio público.

Segundo Efe (2013), a população do Distrito passou de 1.864 habitantes em 1991 para 13.513 habitantes em 2010. Com o aumento populacional na região e o intenso parcelamento de terras, o plano diretor foi mudado para incorporar a urbanização do Distrito do Rio Vermelho. Porém, esta medida não foi acompanhada de planejamento por parte dos órgãos públicos, resultando na criação de áreas de risco em ambientes sujeitos a alagamento, especialmente naquelas áreas úmidas presentes no interior do terraço marinho, mais precisamente o terraço marinho com retrabalhamento eólico mais plano descrito por Luiz e Lamas (2017). Esta feição de relevo do Distrito foi alvo de maior ocupação por moradias e arruamentos em função de seus terrenos mais planos e baratos.

\section{Materiais e métodos}

As áreas úmidas presentes no terraço marinho do Distrito de Rio Vermelho foram identificadas e mapeadas com maior detalhe com o uso dos produtos do aerolevantamento realizado pela Secretaria de Estado do Desenvolvimento Econômico Sustentável de Santa Catarina (SDS) entre os anos de 2010 e 2013, sendo eles o MDT (Model Digital Terrain) e as ortofotos digitais. O MDT possui precisão altimétrica de 1 metro e grid com resolução espacial de 1 metro, enquanto as ortofotos digitais apresentam pixels georrefenciados e resolução espacial de 0,39 $\mathrm{m}$.

Com estes materiais, utilizando ferramentas do software ArcGIS 10.1, foi elaborada uma base de mapeamento assim como foram restituídas as curvas de nível a partir do MDT para ajudar na identificação de áreas mais rebaixadas no relevo. A rede de drenagem e outros corpos d'água foram restituídos pela própria equipe responsável pelo aerolevantamento citado anteriormente. Alguns rios foram corrigidos para a presente pesquisa a partir do controle visual com uso das ortofotos digitais. Um relevo sombreado foi confeccionado com uso da ferramenta hillshade presente na extensão 3D Analyst do ArcGIS 10.3, empregando o MDT como arquivo raster de base, o que auxiliou também na identificação de áreas mais baixas no relevo.

A interpretação visual das ortofotos digitais, auxiliada com o uso do relevo sombreado e das curvas de nível, permitiu uma demarcação de áreas úmidas no 
terraço marinho do Rio Vermelho. Como critério para delimitação foram observadas as áreas mais baixas em relação ao seu entorno ou que apresentam manchas mais escuras em sua superfície devido à proximidade do lençol freático. Estas áreas foram divididas em duas categorias: áreas sempre úmidas e/ou alagadas e áreas com umidade quando o lençol sobe em momentos de chuva intensas e/ou continuadas, estas últimas foram denominadas de franjas de umidade.

Visitas a campo ajudaram a corrigir problemas da interpretação e permitiram a realização de sondagens manuais em algumas áreas para encontrar a profundidade do lençol freático em um período de chuvas continuadas em setembro de 2015.

Para o entendimento da dinâmica dos eventos de alagamentos foram realizadas consultas junto à Diretoria Municipal de Defesa Civil de Florianópolis e entrevistas com moradores mais antigos do Distrito. Para os eventos de alagamento mais marcantes na memória das pessoas e registrados na defesa civil municipal, foi buscado o comportamento das precipitações nestes eventos a partir do levantamento de dados pluviométricos fornecidos pela Empresa de Pesquisa Agropecuária e Extensão Rural de Santa Catarina (EPAGRI). Também foram consultados dados do trabalho de Efe (2013) sobre áreas alagadas no Rio Vermelho e a urbanização do local.

\section{Resultados e discussões}

Os alagamentos em Geomorfologia são considerados fenômenos da dinâmica natural que implicam em acúmulo de água em superfície, resultado da subida do lençol freático e/ou da chegada de água do escoamento superficial nos terrenos mais baixos do que seu entorno. A drenagem dos terrenos é deficiente por falta de gradiente de escoamento. Para Castro (2003), o alagamento é o acúmulo momentâneo da água em determinados locais por deficiência do sistema de drenagem. Esta definição é incompleta, pois este acúmulo pode ocorrer naturalmente nas depressões do terreno.

Por outro lado, inundações são fenômenos ligados às cheias dos rios, o que leva ao transbordamento do seu fluxo sobre os terrenos vizinhos ao seu leito (BRASIL, 2007). As planícies fluviais podem ser invadidas pelas águas do extravasamento dos rios e também pela subida do lençol freático. As inundações costumam ser periódicas, porém podem ocorrer episódios de maior magnitude e menor frequência, causando muitas perdas e danos (White, 1945). 
No Distrito de Rio Vermelho, diferentes áreas úmidas ou franjas de umidade foram identificadas nas formas de relevo ali presentes (SANTOS; LUIZ, 2016), tais como aquelas ligadas à rede de drenagem natural (trechos das planícies fluviais do rio João Gualberto e do rio Vermelho e cabeceiras de canais de primeira ordem), às planícies flúvio-lagunares, às depressões inter-dunares e aos terrenos úmidos no interior do terraço marinho. Cada uma delas tem sua dinâmica própria de saturação de água de acordo com a entrada das precipitações. Figuras 2, 3 e 4.

As áreas úmidas ligadas à rede de drenagem apresentam aumento de umidade e espelho d'água na superfície por conta da subida do lençol freático e do transbordamento dos rios em episódios de precipitações intensas e/ou excepcionais. Contudo, a planície do rio Vermelho quase sempre tem água livre sobre seus terrenos por causa de seu baixo gradiente de escoamento, assim como algumas cabeceiras de drenagem com nascentes difusas. 


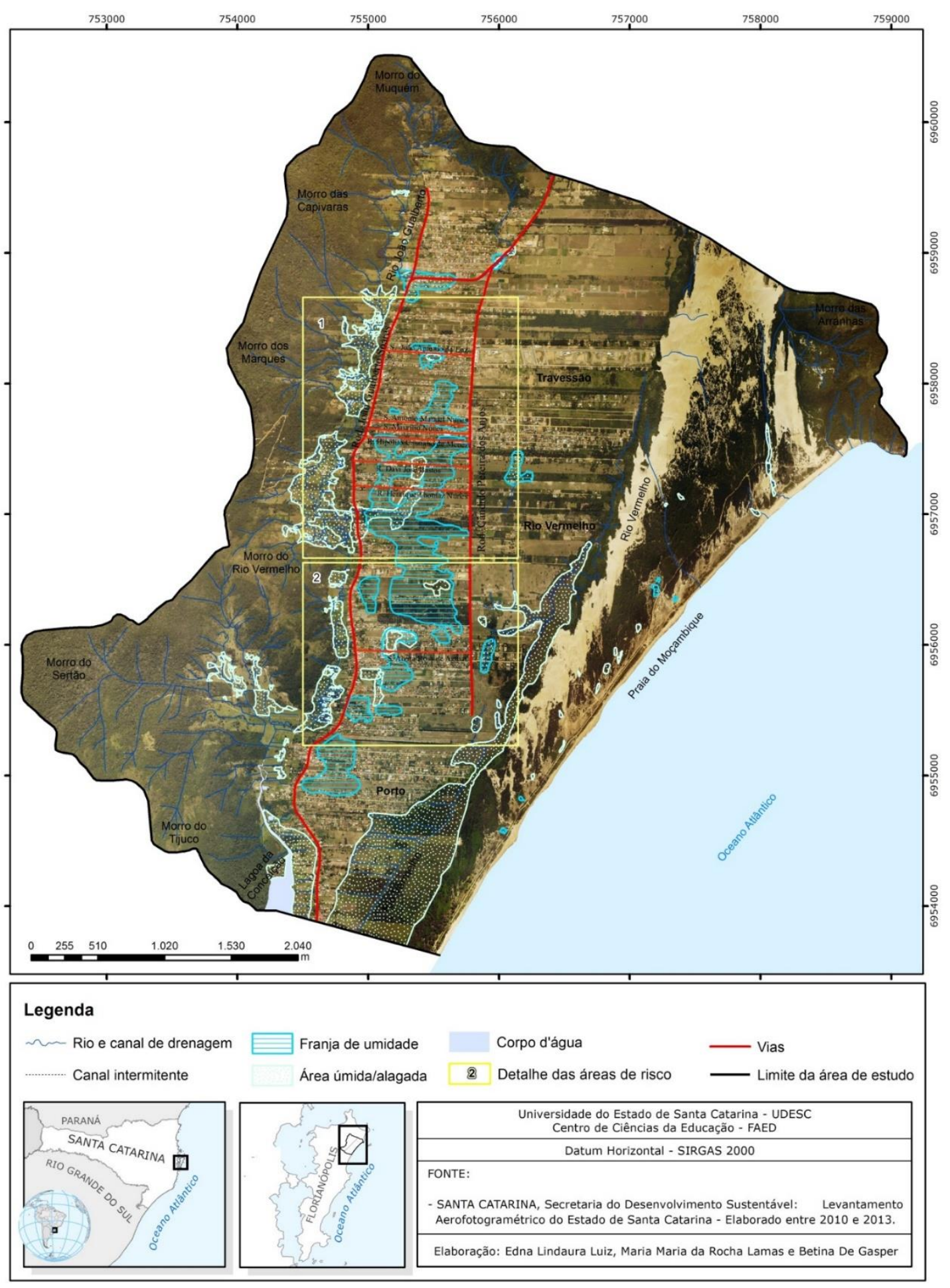

Figura 2. Mapa das áreas úmidas e franjas de umidade presentes no Distrito de Rio Vermelho, Florianópolis/SC. Elaboração dos autores. 


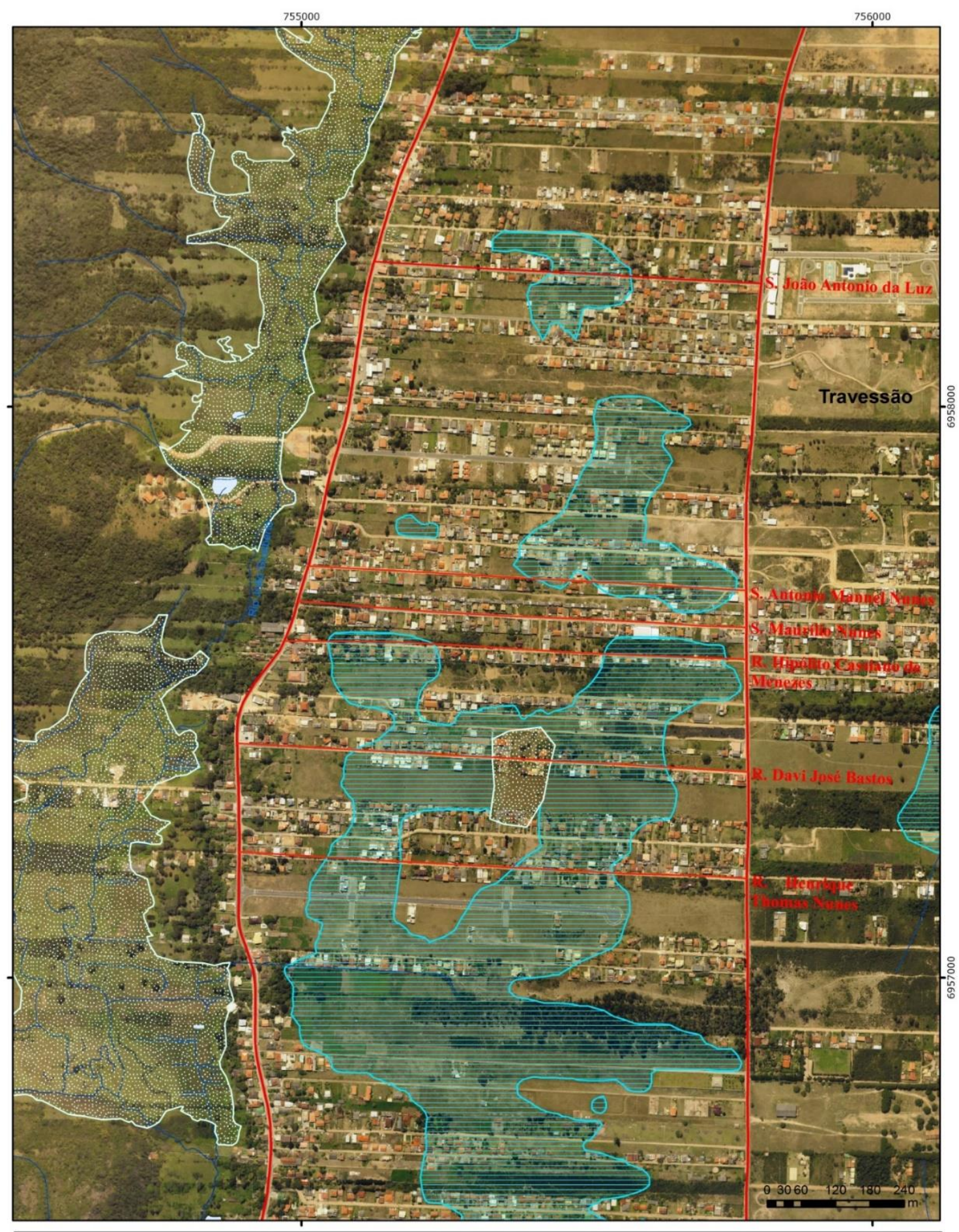

\section{Legenda}

$\sim$ Rio e canail de drenagem

... Canal intermitente

Franja de umidade

Área úmida/alagada

Corpo d'água

Fonte: SANTA CATARINA,

Secretaria de Desenvolvimento

Sustentável - Levantamento

aerofotogramétrico, 2010 a 2013 .

Figura 3. Mapa de detalhe 1 das áreas úmidas e franjas de umidade da parte norte do terraço marinho com algumas ruas (R.) e servidões (S.) atingidas por alagamentos. Elaboração dos autores. 


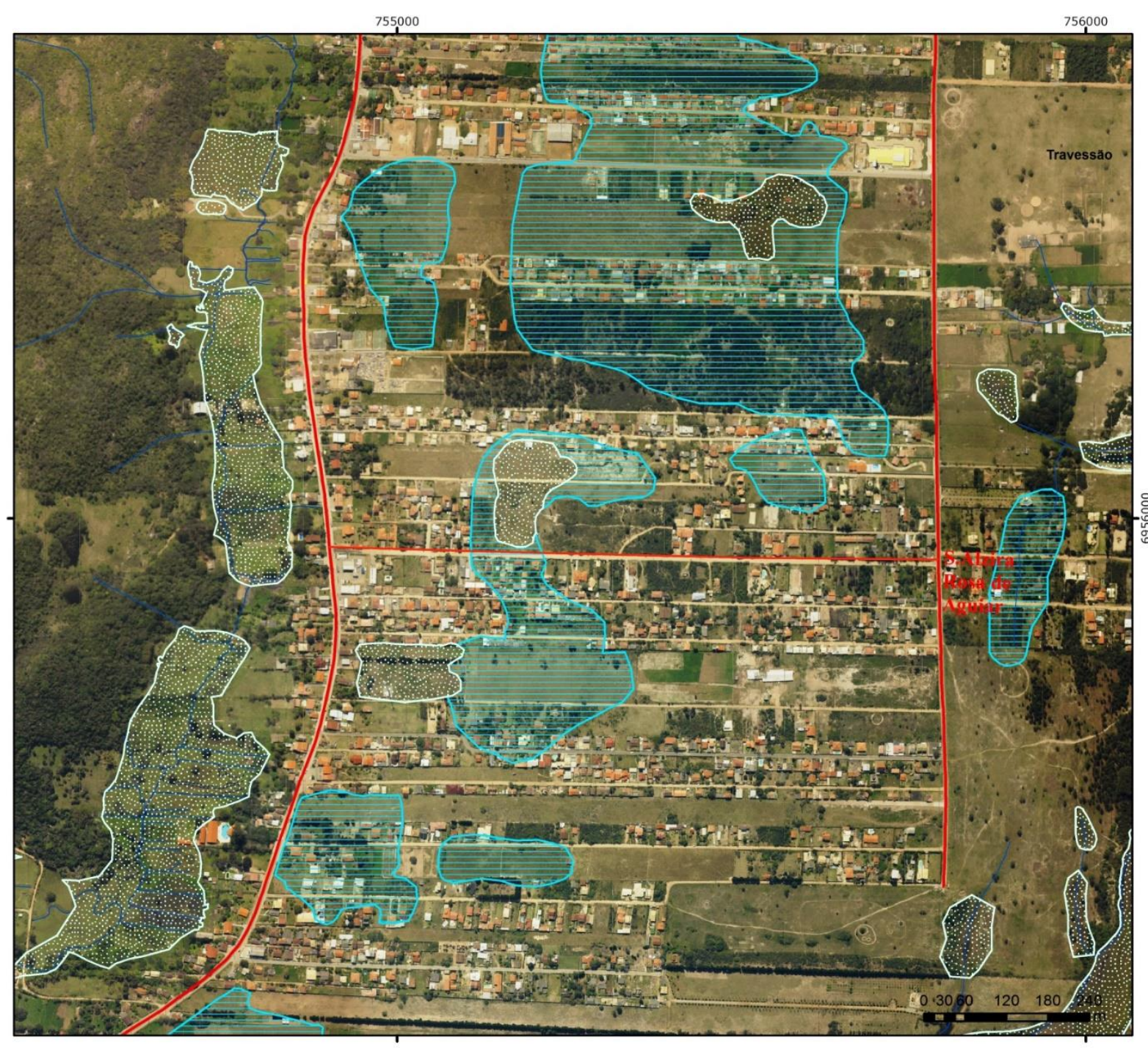

\begin{tabular}{|c|c|c|c|}
\hline \\
\hline \multirow{2}{*}{$\begin{array}{l}\text { Legenda } \\
\text { Rio e canail de drenagem } \\
\text { Canal intermitente }\end{array}$} & Franja de umidade & \multirow[t]{2}{*}{ Vias } & \multirow{2}{*}{$\begin{array}{l}\text { Secretaria de Desenvolvimento } \\
\text { Sustentável - Levantamento } \\
\text { aerofotogramétrico, } 2010 \text { a } 2013 .\end{array}$} \\
\hline & Área úmida/alagada & & \\
\hline
\end{tabular}

Figura 4. Mapa de detalhe 2 das áreas úmidas e franjas de umidade da parte sul do terraço marinho com uma servidão (S.) atingida por alagamento. Elaboração dos autores.

As planícies flúvio-lagunares também teriam água livre em sua superfície, pois apresentam altitudes muito próximas do nível do mar (cerca de $1 \mathrm{~m}$ ), porém sofreram drenagem artificial na década de 1960, o que rebaixou o lençol freático (HERBERLE; MARIMON; LUIZ, 2013) (Figura 5). Por isso, atualmente só ficam alagadas com chuvas intensas e/ou continuadas. 


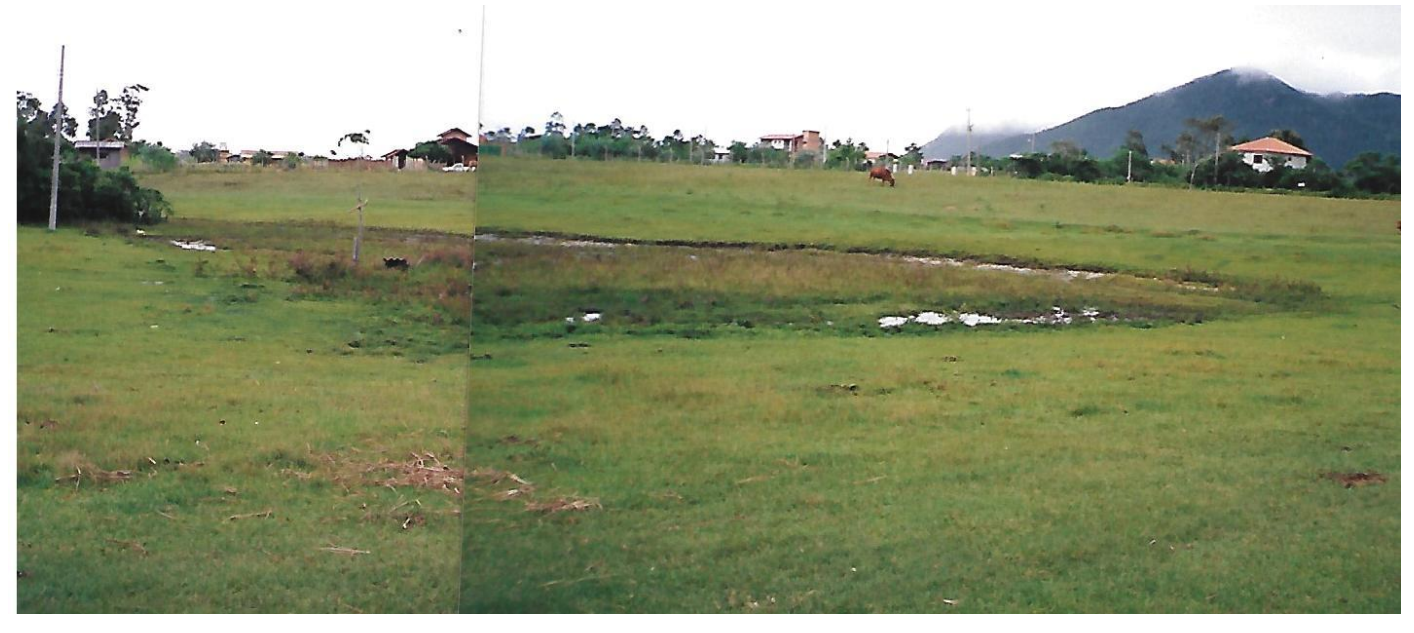

Figura 5. Área úmida do tipo cabeceira de drenagem no interior do terraço marinho. Nascente difusa de afluente do rio Vermelho. Foto: Edna Luiz. Data: 09/06/2011.

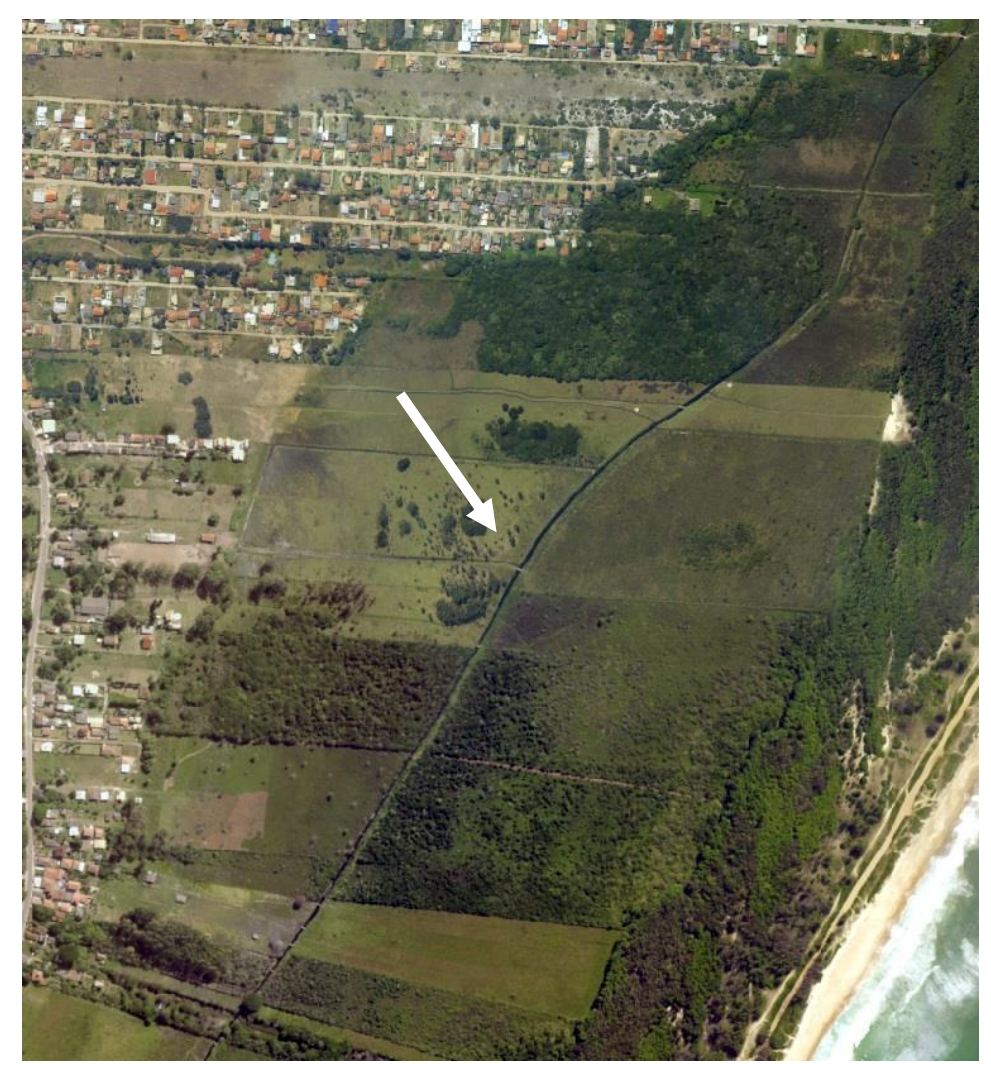

Figura 6. Planície Flúvio-Lagunar. Observar o canal construído no centro da planície (seta branca), que liga o rio Vermelho à lagoa da Conceição, para drenagem desta área.

Fonte: Ortofotos digitais - Secretaria de Desenvolvimento Sustentável de Santa Catarina, 2010-2013. Escala aprox.: 1:6.000.

As depressões inter-dunares podem se configurar em pequenos lagos no meio do campo de dunas quando as chuvas são intensas durante vários dias. E, os terrenos úmidos no interior do terraço marinho são os tipos de áreas úmidas com o 
menor teor de umidade na paisagem. Em função dessa condição, estes terrenos foram locais que sofreram urbanização nos últimos anos, criando áreas de risco.

O funcionamento das áreas úmidas presentes no interior do terraço marinho arenoso é muito interessante, pois suas formas nem sempre são marcadamente mais rebaixadas em relação ao seu entorno e, ainda, o aumento do teor de umidade e a formação de água livre na sua superfície são devidos quase que exclusivamente a subida do lençol freático, o que configura um fenômeno de alagamento.

O terraço marinho arenoso pode ser considerado um grande aquífero por sua natureza muito permeável, sendo que este aquífero está na superfície recebendo diretamente a infiltração da água das chuvas. Contribui ainda mais para o processo de infiltração, a forma levemente aplainada deste terraço. $O$ basculamento que ele apresenta de norte para sul, variando de altitudes de $28 \mathrm{~m}$ até $08 \mathrm{~m}$, também permite o fluxo de água subbsuperficial nesta direção, acumulando maior umidade na sua porção centro-sul.

Moradores antigos do Distrito explicam que precisa chover muito e durante vários dias para acontecer este fenômeno de alagamento no terraço marinho, mas que a drenagem destes locais depois que terminam as chuvas é muito lenta. Eles também têm a consciência de que é o lençol subindo nos terrenos que provoca os alagamentos no terraço marinho, especialmente nas baixadas, e que a água vai drenando por dentro do solo de norte para sul e, por isso, os lugares mais ao sul demoram mais para secar. Outra questão citada pelos moradores mais antigos da comunidade é que onde havia a cobertura de vegetação de regeneração composta de vassorais (Baccharis sp.) a intensidade dos episódios de alagamentos era menor. Provavelmente porque esta espécie precisa de terrenos secos para se desenvolver.

Em função das áreas mais suscetíveis a alagamentos sobre o terraço marinho normalmente estarem secas ao longo do tempo, elas eram aproveitadas pelos colonos açorianos para pastagens para o gado bovino ou deixadas nos estágios de regeneração da vegetação nativa como uma fonte de lenha. Quando ocorria um episódio de alagamento, era simplesmente retirar o gado e levá-lo para pastar em outros locais mais secos. Alguns moradores antigos explicaram que em episódios de alagamentos mais intensos, as áreas com solo úmido do entorno se ampliavam muito e alcançavam as plantações de mandioca, provocando o apodrecimento da raiz da planta e certo prejuízo, mas nada muito grave. Esse conhecimento do lugar permitia uma convivência com a dinâmica natural e não gerava perdas e danos aos 
moradores. Desta forma, as áreas suscetíveis a alagamentos no terraço não configuravam em áreas de risco.

Com o parcelamento do solo que começou a ser executado sobre os terrenos do terraço marinho a partir da década de 1990, como colocado anteriormente, as áreas sujeitas a alagamento passaram a receber arruamentos e edificações, sendo o local de moradia de um grande contingente populacional. As pessoas que moram nestes locais são mais vulneráveis aos fenômenos de alagamento porque são migrantes de outros municípios de Santa Catarina ou ainda de outros Estados e por isso não conheciam a dinâmica natural do lugar para onde se mudaram.

Em trabalhos de campo, foi possível observar arruamentos e lotes implantados em áreas deprimidas do interior do terraço (Figura 7). Também foram encontrados muitos trechos de lotes e arruamentos com aterros de saibro e de entulho de construção civil que ainda assim apresentavam muita umidade após uma sequência de vários dias com sol, como pode ser observado na Figura 8.

Em 1983, houve um evento de alagamento que durou seis meses em algumas porções do terraço marinho, obrigando os poucos moradores que ali viviam na época a fazerem caminhos mais longos para se deslocarem de suas residências até o centro do Distrito. Em alguns locais, era necessário usar até canoas. O tempo de duração deste evento se deve ao comportamento das chuvas que foram muito intensas e continuadas durante todo aquele ano, com destaque para o mês de julho (Figura 9), quando choveu $513 \mathrm{~mm}$ (conforme Tabela 1), valor muito superior à média mensal que é de apenas $82,6 \mathrm{~mm}$. Nos meses seguintes, as chuvas continuaram, não permitindo a drenagem do terreno. Segundo relato dos moradores, existiam lagoas no interior do terraço marinho do Rio Vermelho, mas os prejuízos não foram significativos. 


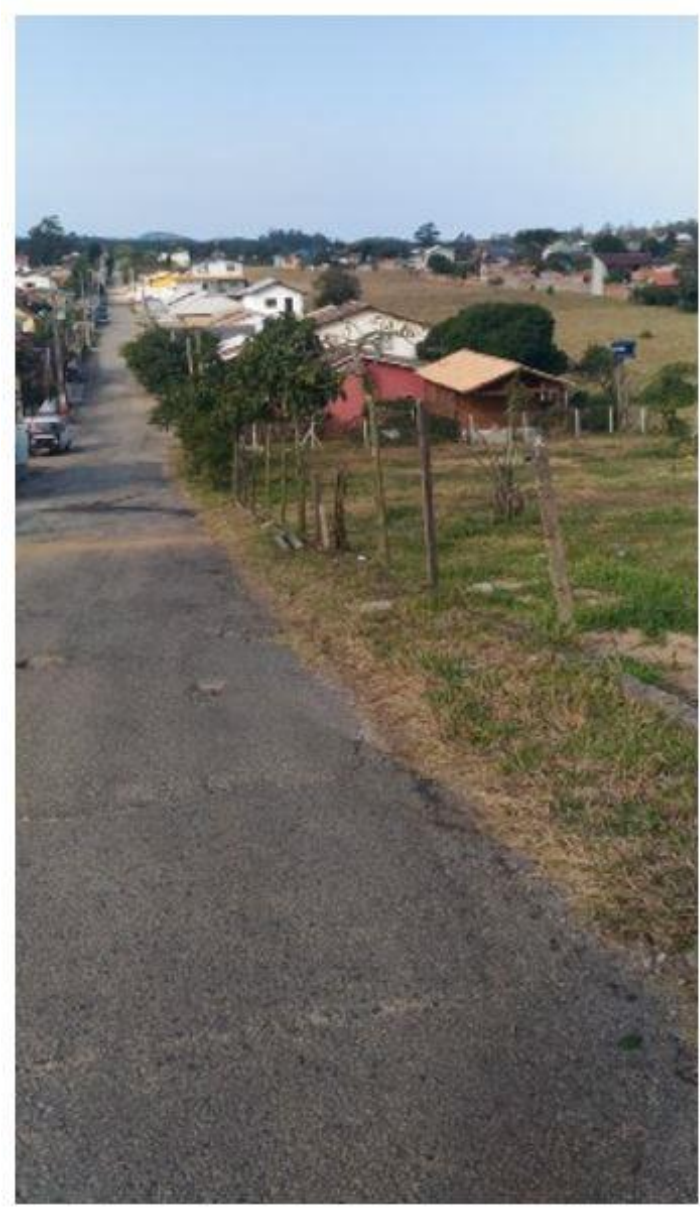

Figura-7. Trecho da rua Davi-José Bastos, Rio - Vermelho, Florianópolis/SC. Observar as construções e arruamento no interior - de uma área deprimida do terraço marinho. Foto: Larissa Anjos Santos. Data: 15/07/2016. I

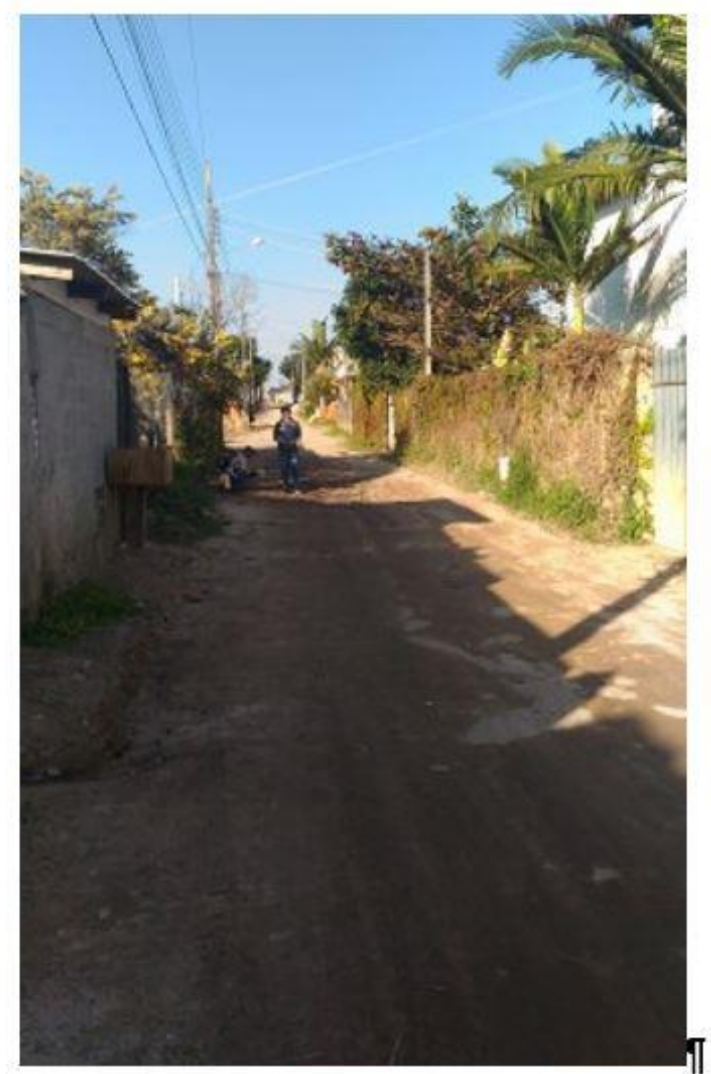

Figura-8. Trecho da rua Hipólito Cassiano deMenezes, Rio - Vermelho, Florianópolis/SC. Observar o-terreno úmido, mesmo com o-diade sol. Foto: Larissa- Anjos - Santos. Data: 15/07/2016. T

१

ๆ

ๆ

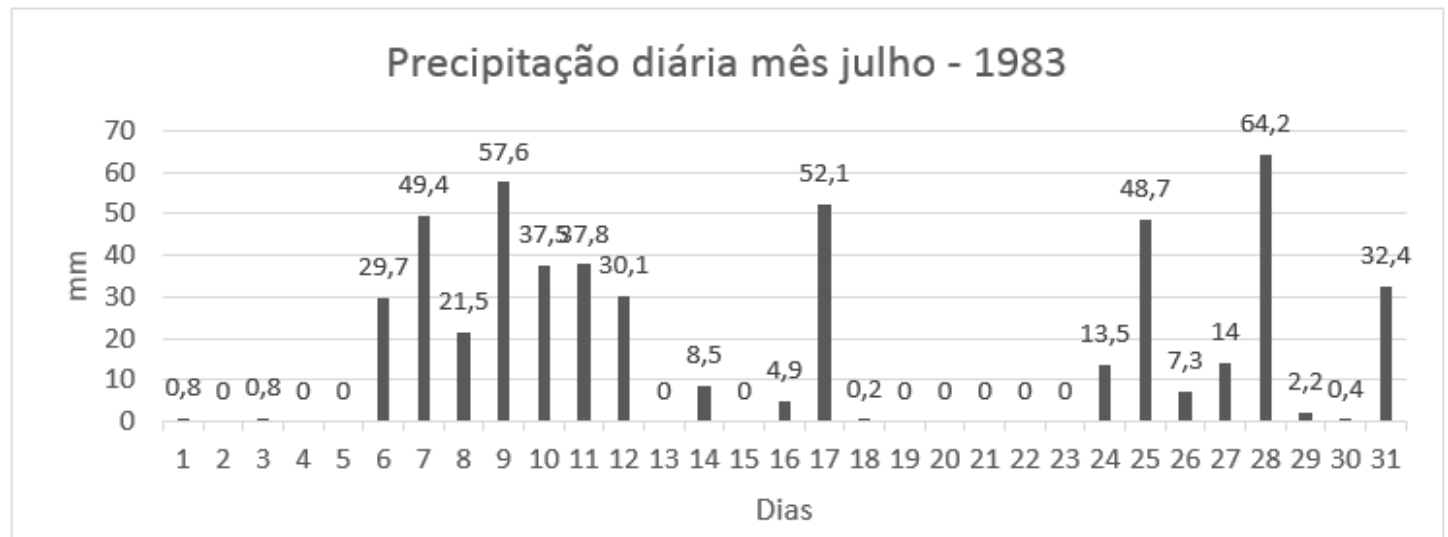

Figura 9. Precipitação diária do mês de julho de 1983 - região da Grande Florianópolis Fonte: Dados da Estação climatológica do Instituto Nacional de Meteorologia (INMET) em São José/SC

Na Figura 9 é possível verificar que houve dois períodos de chuvas intensas e continuadas no mês de julho de 1983, do dia 6 até o dia 17 e depois do dia 24 até o dia 31. Isto gerou muita infiltração de água no solo arenoso do terraço com 
consequente subida de lençol freático, além da formação de escoamento superficial se acumulando nas áreas mais baixas.

Tabela 1. Totais de precipitação mensal dos anos 1983, 1995, 2008, 2009, 2010 e 2011 na Estação Climatológica de São José/SC

\begin{tabular}{l|l|l|l|l|l|l|l|l|l|l|l|l|l}
\hline & $\begin{array}{l}\text { Jan. } \\
(\mathrm{mm})\end{array}$ & $\begin{array}{l}\text { Fev. } \\
(\mathrm{mm})\end{array}$ & $\begin{array}{l}\text { Mar. } \\
(\mathrm{mm})\end{array}$ & $\begin{array}{l}\text { Abr. } \\
(\mathrm{mm})\end{array}$ & $\begin{array}{l}\text { Mai. } \\
(\mathrm{mm})\end{array}$ & $\begin{array}{l}\text { Jun. } \\
(\mathrm{mm})\end{array}$ & $\begin{array}{l}\text { Jul. } \\
(\mathrm{mm})\end{array}$ & $\begin{array}{l}\text { Ago. } \\
(\mathrm{mm})\end{array}$ & $\begin{array}{l}\text { Set. } \\
(\mathrm{mm})\end{array}$ & $\begin{array}{l}\text { Out. } \\
(\mathrm{mm})\end{array}$ & $\begin{array}{l}\text { Nov } \\
(\mathrm{mm})\end{array}$ & $\begin{array}{l}\text { Dez. } \\
(\mathrm{mm})\end{array}$ & $\begin{array}{l}\text { Total } \\
\text { anual } \\
(\mathrm{mm})\end{array}$ \\
\hline $\mathbf{1 9 8 3}$ & 279,3 & 236,3 & 151,6 & 178,3 & 205 & 177,3 & 513,6 & 119,3 & 180,9 & 72,8 & 192,3 & 367,1 & $2.673,8$ \\
\hline $\mathbf{1 9 9 5}$ & 367,6 & 247,2 & 239,3 & 36,4 & 5,7 & 107,3 & 56 & 60,2 & 105,9 & 136,2 & 115,8 & 563,2 & $2.040,8$ \\
\hline $\mathbf{2 0 0 8}$ & 289,4 & 361,9 & 360,8 & 246,9 & 77,8 & 73,4 & 7,3 & 66,4 & 204,6 & 274 & 642,2 & 212,4 & $2.817,1$ \\
\hline $\mathbf{2 0 0 9}$ & 169,4 & 118,5 & 201,9 & 307 & 71,1 & 48,8 & 112,5 & 143,2 & 225,3 & 130,2 & 109,9 & 177,1 & $1.814,9$ \\
\hline $\mathbf{2 0 1 0}$ & 173,8 & 148,7 & 349 & 190,1 & 334,6 & 119,1 & 104,5 & 67 & 126,5 & 122,9 & 150,7 & 166,4 & $2.053,3$ \\
\hline $\mathbf{2 0 1 1}$ & 317,7 & 277,2 & 331,8 & 52,7 & 157,1 & 85,4 & 141,6 & 432,1 & 226,3 & 123,2 & 69,3 & 255,9 & $2.470,3$ \\
\hline
\end{tabular}

Fonte: Centro de Informações de Recursos ambientais e de Hidrometeorologia de Santa Catarina Empresa de Pesquisa Agropecuária e Extensão Rural de Santa Catarina (CIRAM-EPAGRI).

Outro evento que marcou a lembrança dos moradores locais foi o de dezembro de 1995 (Figura10), quando choveu 563,2mm, sendo que grande parte deste total foi concentrada em três dias (dias 24, 25 e 29). Foram episódios com mais de $100 \mathrm{~mm}$ diários, com destaque para o dia 25 em que choveu $207 \mathrm{~mm}$. Nesta época, já havia muitas pessoas morando sobre o terraço e houve algumas perdas e danos materiais por conta dos alagamentos. Efe (2013) comenta que o corpo de bombeiros chegou a visitar alguns locais e drenar a água com bombas, contudo, naquele momento, a drenagem natural também ocorreu mais rápido do que acontece atualmente, possivelmente em função do tempo mais estável dos dias seguintes e da menor ocupação do solo a época.

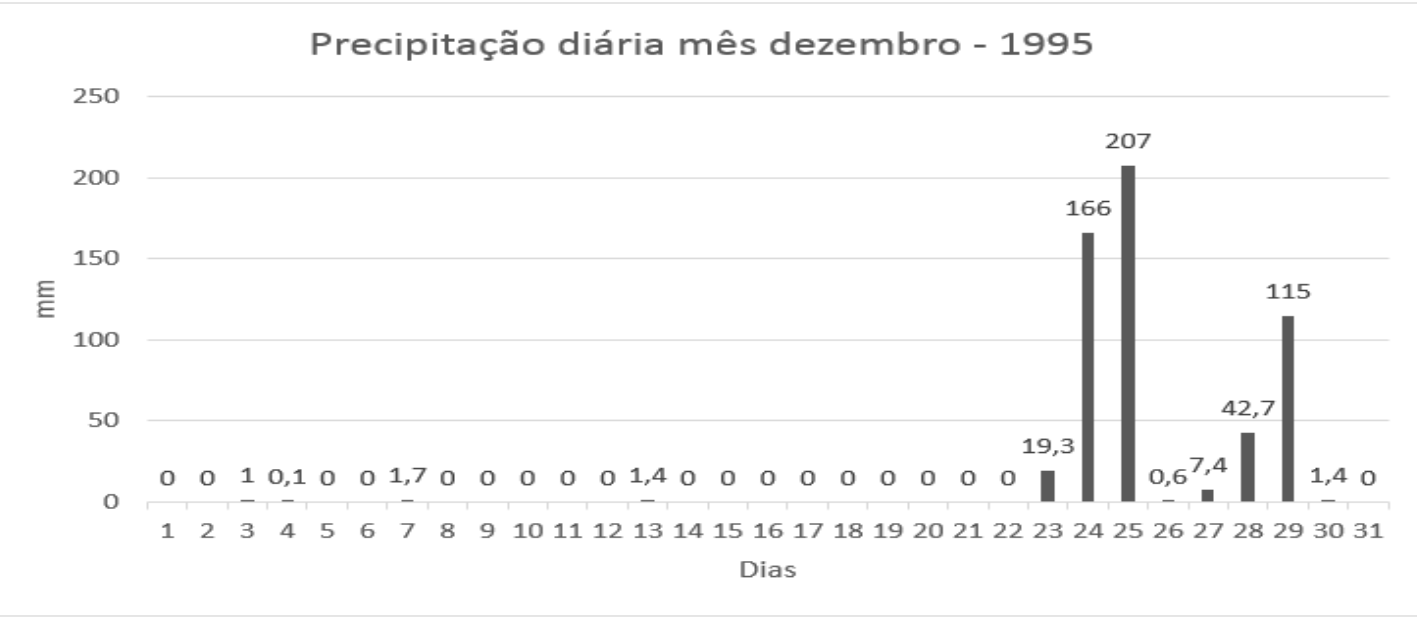

Figura 10. Precipitação diária do mês de dezembro de 1995 - região da Grande Florianópolis. 
Fonte: Dados da Estação climatológica do Instituto Nacional de Meteorologia (INMET) em São José/SC

Nos últimos anos, o aumento da urbanização sobre o terraço marinho gerou muitos problemas para a população local nos episódios de alagamentos, sendo que também alguns destes anos foram muito chuvosos, tais como 2008 (642,2mm só em novembro) e 2011 (432mm em agosto) de acordo com dados climatológicos da Empresa de Pesquisa Agropecuária e Extensão Rural de Santa Catarina (EPAGRI). Segundo a Defesa Civil do município de Florianópolis, entre os anos de 2008 e 2011, o terraço marinho do Rio Vermelho foi atingido por sete eventos de alagamento e os locais mais atingidos estavam situados:

- na rodovia Cândido Pereira dos Anjos (onde foi realizada uma obra de macrodrenagem pela Prefeitura).

- entre as ruas Davi José Bastos e Hipólito Cassiano de Menezes, a oeste.

- entre as ruas Henrique Thomas Nunes e Antônio Manoel Nunes, a leste.

- na servidão Alzira Rosa Aguiar, pois segundo os moradores, já existiu um lago ali.

Nestes eventos dos anos de 2008 e de 2011, a Defesa Civil Municipal quantificou os principais prejuízos:

- Quantidade estimada de residências atingidas - 119 por evento;

- Quantidade de pessoas atingidas diretamente - 476 por evento;

- Valor estimado das melhorias nas residências em virtude de danos quanto à estrutura em cada evento - $\mathrm{R} \$ 952.000,00$;

- Valor estimado pela perda de bens móveis em cada evento - $R \$ 595.000,00$.

Os eventos de alagamento dos anos de 2008, 2009 e 2011 tiveram comportamentos diferentes entre si, provavelmente acompanhando os episódios de chuvas que também foram diferenciados nestes anos. Em novembro de 2008 (Figura 11), quase todos os dias registraram totais de precipitação aliado ao evento do dia 23 , em que ocorreu um episódio de chuva muito intensa, $160 \mathrm{~mm}$. Sendo assim, a junção da frequência com a intensidade da chuva promoveu os alagamentos longos e intensivos na área de estudo. Em abril de 2009, o que resultou em alagamentos no terraço arenoso não foi especificamente a presença contínua da precipitação no decorrer do mês, mas o grande volume de chuva num período de cinco dias (de 22 a 26 de abril), com ênfase no dia 23, em que o volume de chuvas chegou a $148 \mathrm{~mm}$ em vinte e quatro horas (Figura 12). 


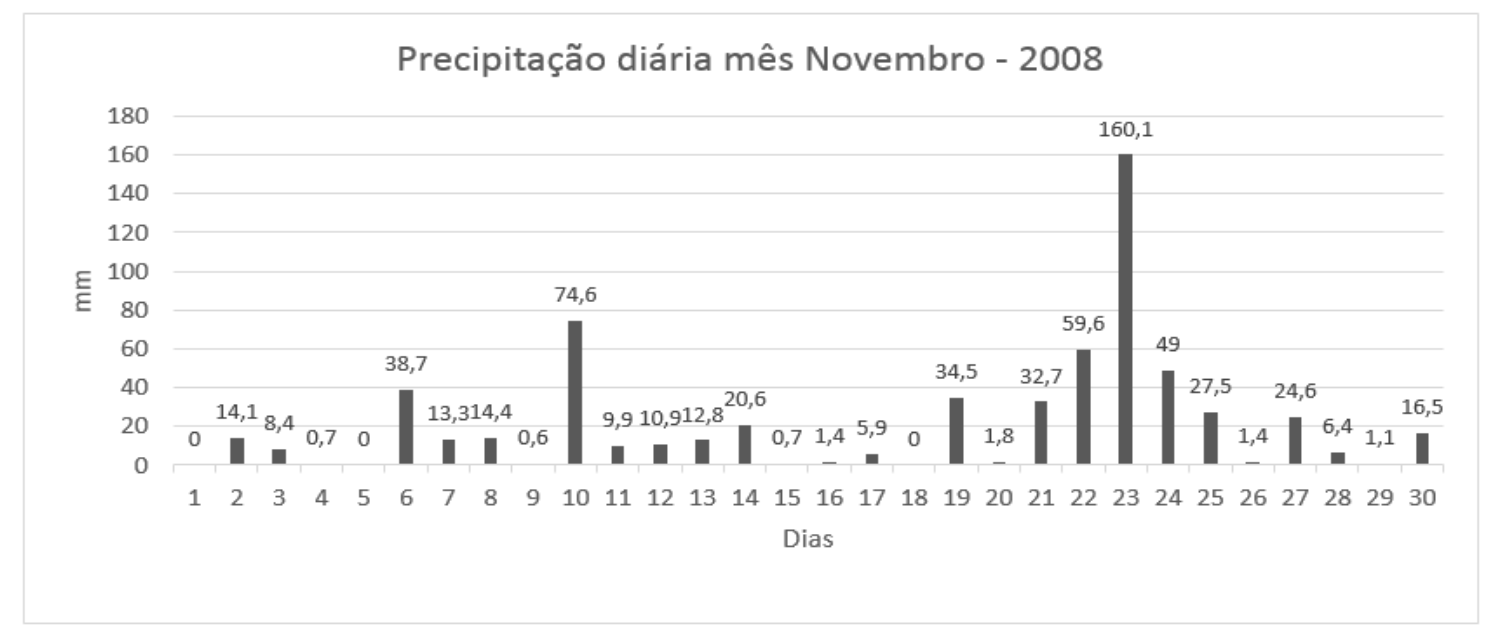

Figura 11. Precipitação diária do mês de novembro de 2008 - região da Grande Florianópolis. Fonte: Dados da Estação climatológica do Instituto Nacional de Meteorologia (INMET) em São José/SC

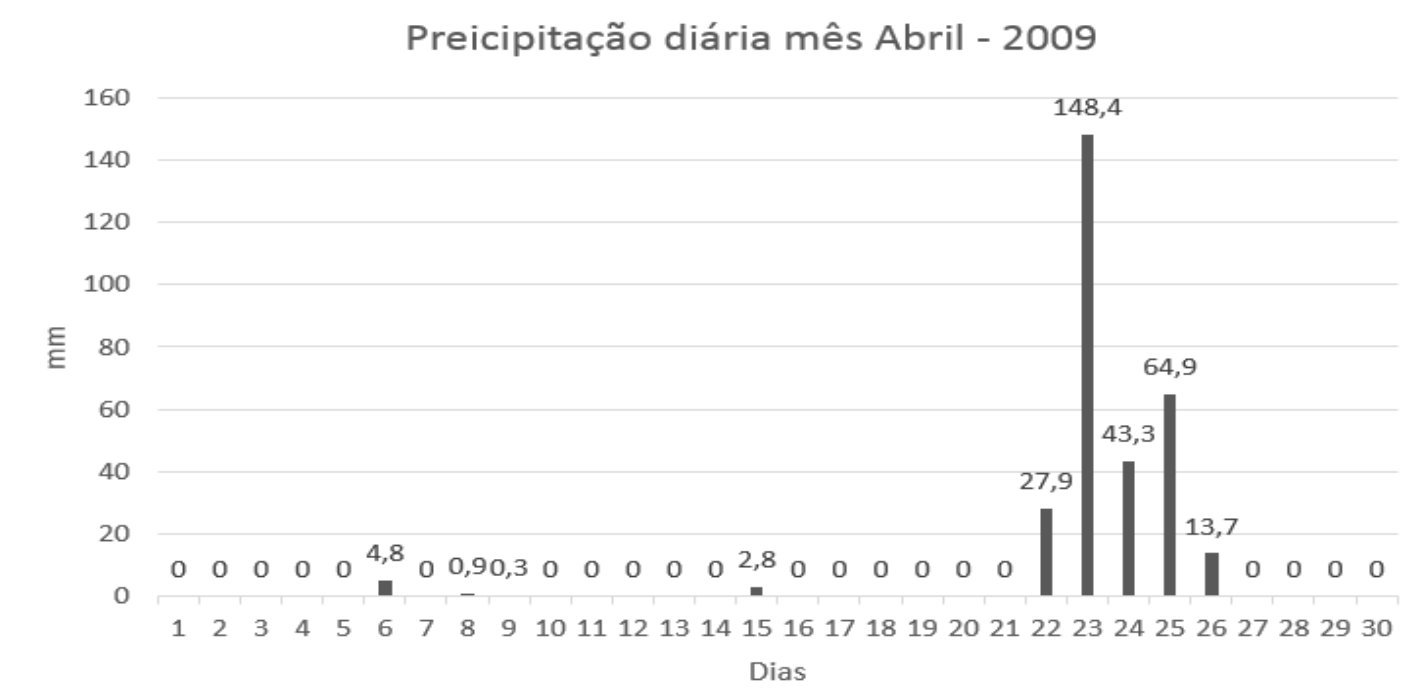

Figura 12. Precipitação diária do mês de abril de 2009 - região da Grande Florianópolis.

Fonte: Dados da Estação climatológica do Instituto Nacional de Meteorologia (INMET) em São José/SC

No evento que ocorreu no ano de 2011 houve uma diferença em relação aos anteriores. Nesse caso em específico, no mês de agosto (Figura 13), com exceção do dia 09 (que choveu cerca de $92 \mathrm{~mm}$ ), a quantidade de chuva não foi tão intensa, porém ela se mostrou frequente ao longo de todo esse mês. 


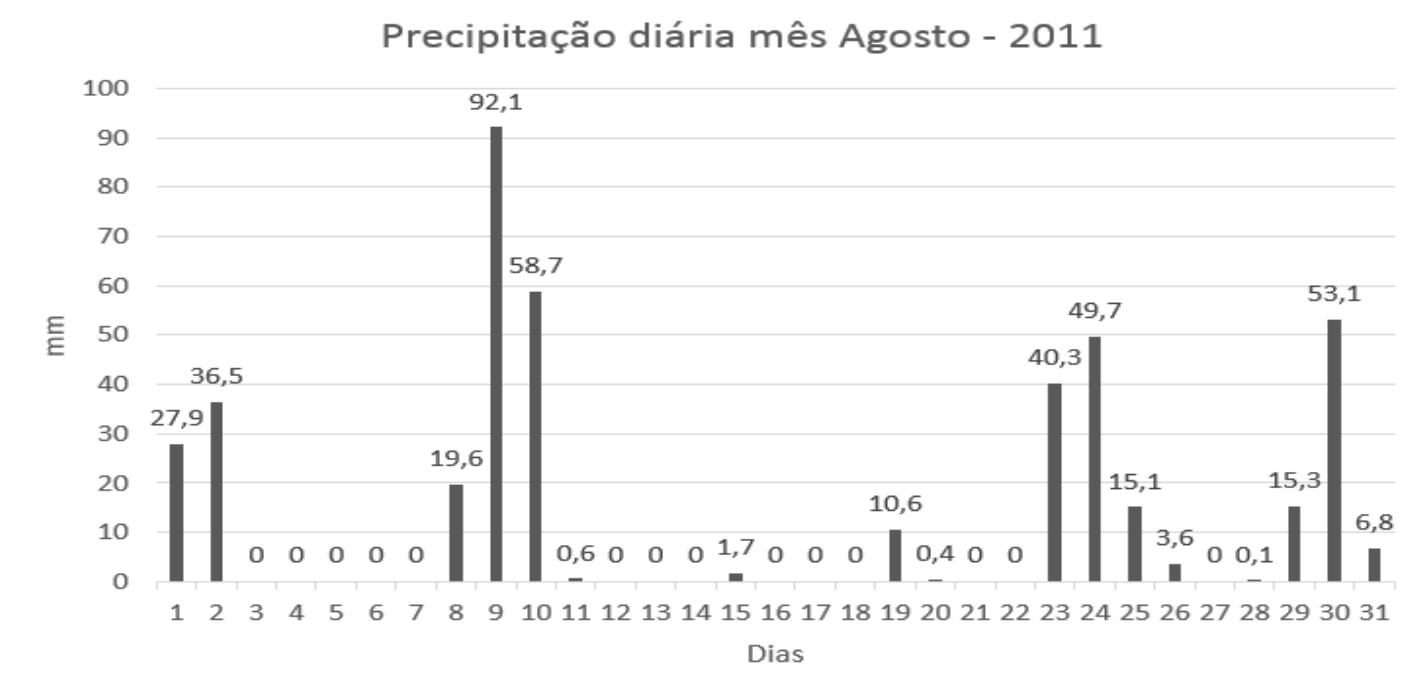

Figura 13. Precipitação diária do mês de agosto de 2011 - região da Grande Florianópolis.

Fonte: Dados da Estação climatológica do Instituto Nacional de Meteorologia (INMET) em São José/SC

Enquanto, no mês seguinte (Figura 14), mesmo havendo poucos dias com precipitação, essas se mostraram intensas já no começo do mês, especialmente no dia 08/09, quando foi registrado um total de $97 \mathrm{~mm}$. Sendo assim, a junção da regularidade da precipitação em um período de 30 dias com dois episódios de chuvas intensas nesse mesmo período (com quase $100 \mathrm{~mm}$ em 24 horas), resultou em um alagamento de grandes proporções e de longa duração nos locais do bairro que estão no terraço marinho.

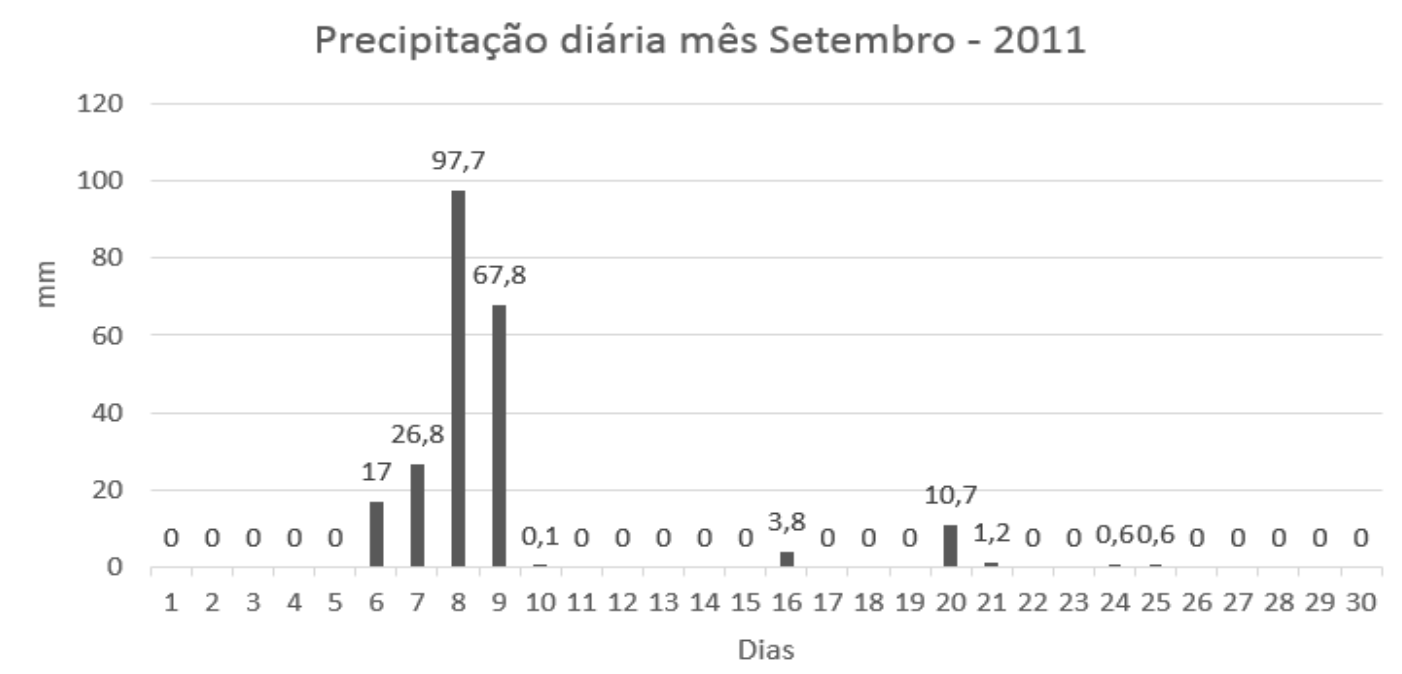

Figura 14. Precipitação diária do mês de setembro de 2011 - região da Grande Florianópolis.

Fonte: Dados da Estação climatológica do Instituto Nacional de Meteorologia (INMET) em São José/SC 
De acordo com os dados diários de precipitação aqui analisados e com os relatos dos moradores, pode-se colocar que há duas características das precipitações que propiciam alagamentos no bairro: a sua frequência e a sua intensidade diária. Em casos extremos, as duas situações podem ocorrer de forma simultânea (como no mês de novembro de 2008, por exemplo). Assim, há eventos de alagamento que começam depois de um período considerável de dias chuvosos antes da água começar a acumular sobre o terreno, como o ocorrido em julho de 1983, em que quase todos os dias do mês tiveram algum registro de precipitação. Por outro lado, houve casos de alagamentos causados pela grande quantidade de chuvas em um dia ou alguns poucos dias, como foram os casos observados em dezembro de 1995 e em abril de 2009. Nessa situação, a quantidade de precipitação varia em torno dos $100 \mathrm{~mm}$ diários, o que faz com que o solo receba grande quantidade de água e não consiga drená-la de maneira eficaz e com velocidade, devido as especificidades do ambiente e as construções que ali foram estabelecidas. Deve-se fazer uma ressalva de que os dados são diários, mas muitas vezes, o episódio de chuva com mais de $100 \mathrm{~mm}$ pode ter ocorrido em um intervalo bem menor do que 24 horas.

Uma questão levantada no trabalho de Efe (2013) em suas entrevistas com moradores do Distrito de Rio Vermelho e também verificada no presente trabalho é a de que a construção de ruas e edificações no terraço marinho dificulta e até pode barrar as águas do escoamento superficial, auxiliando no alagamento de alguns pontos que normalmente não alagavam, como o caso da servidão Maurílio Nunes (Figura 3). Estas barreiras também podem barrar a drenagem natural do terreno abaixo da superfície. Desta forma, a ocupação humana inadequada do terraço marinho no Distrito do Rio Vermelho também aumenta a suscetibilidade ao fenômeno do alagamento e não apenas a vulnerabilidade. Portanto, este tipo de ocupação cria as áreas de risco a alagamentos, pois amplia a suscetibilidade ao perigo em si e ainda aumenta a vulnerabilidade da população.

A planície do rio João Gualberto que sempre foi usada como pastagem ou deixada com sua vegetação nativa, atualmente vem recebendo canais de drenagem e aterros para implantação de loteamentos o que representa a criação de mais áreas de risco no Distrito do Rio Vermelho. Moradores mais antigos têm tentando alertar o poder público do problema de deixar estas áreas serem urbanizadas, mas as obras seguem acontecendo. A presença de aterros em certos trechos da planície pode representar também barreiras ao escoamento das águas de inundação ou 
provenientes da subida do lençol (alagamentos) de trechos mais ao norte dela, o que expande o problema para locais diferentes das áreas loteadas.

Brasil (2007) apresenta medidas estruturais e não-estruturais para se diminuir os riscos a partir da diminuição das ameaças e/ou da vulnerabilidade da população, buscando a convivência com os níveis de risco de forma razoável, com padrões de segurança para o patrimônio e as vidas humanas. Pode-se conviver com o risco desde que de forma aceitável, adaptando a comunidade ao fenômeno perigoso. Medidas estruturais são aquelas que envolvem soluções de engenharia, enquanto medidas não estruturais se relacionam com iniciativas dentro de políticas urbanas, planejamento urbano, plano de defesa civil e educação (BRASIL, 2007; PALACIOS et al., 2005).

São medidas estruturais e não-estruturais passíveis de serem aplicadas ao caso dos eventos de alagamento no bairro Rio Vermelho baseado no que é apresentado por Palacios et al. (2005):

- análise e avaliação dos riscos já instalados, com setorização das áreas de risco;

- criação de normas de ordenamento territorial e de uso do solo pelo poder público que diminuam os riscos (atacando a ameaça ou a vulnerabilidade), ou que evitem que novas áreas de risco sejam criadas;

- proposição de usos alternativos para terrenos ou edificações com maior grau de risco. Neste caso, seriam exigidas desapropriações e remoção da população para locais mais seguros;

- elaboração de normatizações para incentivar as construções adaptadas às áreas de risco. No caso dos eventos de alagamento do Rio Vermelho, poderiam ser pensados projetos de construções soerguidas, com usos alternativos para o andar térreo;

- capacitação da comunidade local para dar respostas coletivas ao risco pensando em uma abordagem preventiva,

- incorporação de discussões sobre áreas de risco nas escolas locais, no caso da área de estudo, a abordagem do conhecimento da dinâmica do meio físico local e os problemas que ela pode gerar para a ocupação humana, além de como fazer a gestão das áreas de risco ali presentes;

- discussão de possibilidades de incentivos econômicos para a redução do risco, tal como a criação de um seguro para os moradores atingidos por alagamentos no Rio Vermelho. 
No caso específico dos alagamentos no Rio Vermelho, deve-se discutir o ordenamento do uso do solo e a implantação de um sistema de alerta e de contingência sobre as chuvas que provocam alagamento. Deve também propor um sistema de drenagem adaptado às condições naturais e de uso e ocupação dos terrenos, visando drenar as águas acumuladas nos episódios de alagamento, inclusive com uso de bombeamentos. As águas bombeadas e drenadas devem passar por tratamento sanitário para serem dispostas nos corpos d'água local, pois podem estar contaminadas pela falta de coleta e tratamento de esgotos no bairro.

Algumas obras de macrodrenagem já foram efetuadas em 2012 nas ruas e servidões que mais alagam segundo dados da Secretaria de Obras da Prefeitura Municipal de Florianópolis. Foi instalado um sistema de escoamento por caixa ou cilindro sem fundo. Contudo, é preciso pensar este sistema para todo o terraço arenoso e, como colocado, anteriormente, tratar estas águas, pois muitos moradores reclamaram de que a destinação delas sem nenhum tratamento poderá contaminar os cursos d'água existentes.

\section{Considerações Finais}

O Distrito de Rio Vermelho em Florianópolis/SC possui em seu território diferentes tipos de áreas úmidas, a maioria delas apresenta água livre na superfície, o que dificulta a ocupação humana. Contudo, as áreas úmidas presentes no interior do terraço marinho arenoso só apresentam água livre quando há dias seguidos de chuva com grande intensidade. Por esta característica, elas acabaram recebendo urbanização nos últimos 25 anos aproximadamente. Os moradores antigos do Distrito conheciam bem a dinâmica deste ambiente dentro do terraço marinho, segundo entrevistas, e por isso usavam-no para pastagens ou deixavam a regeneração natural da vegetação nativa. A ocupação atual do terraço marinho e, especialmente de seus terrenos úmidos, com arruamentos e edificações são em sua maioria fruto de parcelamentos irregulares do solo, o que dificultou ainda mais o entendimento do ambiente e o planejamento de onde e como construir. Cada comprador dos lotes só pensava em sua propriedade e não observava sua parcela dentro de uma perspectiva de forma de relevo e do sistema de drenagem natural.

Agravando o problema da urbanização das áreas úmidas dentro do terraço está a ocorrência de anos mais úmidos dentro da variabilidade climática natural, como ocorreu no período de 2008 a 2011. Nestes anos, os eventos de alagamento 
provocaram uma grande quantidade de perdas e danos materiais, com necessidade de auxílio da Defesa Civil Municipal e da Prefeitura Municipal para bombear a água dos terrenos e residências. Os alagamentos felizmente não causam mortes, mas são desastrosos para os moradores que perdem seus bens e não tem como mudar de residência por falta de recursos financeiros, uma vez que já compraram propriedades nestes locais por elas serem mais baratas.

A falta de conhecimento da dinâmica do ambiente e a baixa renda dos moradores, associadas com seus prejuízos nos eventos de alagamentos recentes, aumenta a sua vulnerabilidade. A urbanização do terraço marinho no Distrito do Rio Vermelho sem um planejamento e atuação do poder público acabou por criar arruamentos e edificações que também funcionam como barreiras ao escoamento natural das águas, o que aumentou a suscetibilidade aos alagamentos. Todos estes fatores criaram as áreas de risco a alagamentos no Distrito. Resolver o problema via diminuição da suscetibilidade aos alagamentos por realização de drenagens artificiais não será uma solução completa porque todo o terraço é um grande aquífero e o gradiente entre estes terrenos e o mar é muito pequeno. Por isso, para resolver o problema deve-se focar mais na questão da vulnerabilidade das pessoas.

Infelizmente, novas áreas de risco estão sendo criadas agora na planície do rio João Gualberto, local que sempre se soube ser suscetível a alagamentos e inundações, com lençol freático muito próximo da superfície. A abertura de loteamentos na planície vai estabelecer nesta área uma população vulnerável aos eventos hidrológicos perigosos, ainda mais se estes futuros moradores não forem oriundos do local e por isso não saberem sobre a dinâmica deste ambiente. O poder público deixou e ainda continua deixando ocorrer parcelamentos do solo em áreas de alagamento e inundação. Além disso, depois da ocupação já consolidada, não existe uma iniciativa de ordenamento territorial adaptado aos problemas que os moradores enfrentam no local.

O não conhecimento da dinâmica natural aumenta a vulnerabilidade da população que já está instalada em áreas de risco, assim como leva a ocupação de novas áreas onde existe a ocorrência de alagamentos e inundações. $O$ conhecimento existente sobre os fenômenos de alagamentos e inundações no Distrito de Rio Vermelho é mais empírico do que técnico-científico e ele vem dos moradores mais antigos do Distrito. Desta forma, o presente trabalho pretende ampliar este conhecimento tanto para a população em geral quanto para nortear as ações do poder público. A partir do conhecimento das áreas de perigos de 
alagamentos e inundações, o poder público pode tomar providências para evitar a ocupação destas áreas, evitando a criação de novas áreas de risco, e também pode fazer a gestão de risco das áreas já ocupadas a partir da implementação de medidas estruturais e não-estruturais mais adequadas à realidade local.

\section{REFERÊNCIAS}

BRASIL. Ministério das Cidades / Instituto de Pesquisas Tecnológicas - IPT. Mapeamento de Riscos em Encostas e Margem de Rios. CARVALHO, C. S; MACEDO, E. S; OGURA, A.T. (organizadores). Brasília: Ministério das Cidades; Instituto de Pesquisas Tecnológicas IPT, 2007. $176 \mathrm{p}$.

CASTRO, A. L. C. Manual de desastres: desastres naturais. Brasília: Ministério da Integração Nacional, 2003. 174 p.

CERRI, L. E. S.; AMARAL, C. P. Riscos Geológicos. In: BRITO, S. N. A.; OLIVEIRA, A. M. S. Geologia de Engenharia. ABGE, São Paulo, 1998. p. 301-310

EFE, I. N. Eventos de alagamento em São João do Rio Vermelho e sua relação com o processo de urbanização local. Monografia (especialização) - Universidade do Estado de Santa Catarina, Centro de Ciências Humanas e da Educação, Especialização em Gestão de Riscos de Desastres para o Desenvolvimento Socioambiental, Florianópolis, 2013. 71p.

HEBERLE, D. A.; MARIMON, M. P. C.; LUIZ, E. L. Unidades de conservação em zonas metropolitanas: origem e perspectivas futuras do Parque Estadual do Rio Vermelho, Florianópolis/SC. In: DIAS, V. L. N. (Org.). Cadernos do Observatório da Grande Florianópolis do Pet de Geografia. 1ed. Florianópolis: Insular, 2013, v. II, p. 46-68.

KOBIYAMA, M.; MENDONÇA, M.; MORENO, D. A.; MARCELINO, I. P. V. de O.,MARCELINO; E. V.; GONÇALVES, E. F.; BRAZETTI, L. L. P.; GOERL, R. F.;MOLLERI, G. S. F., RUDORFF, F. DE M.. Prevenção de Desastres Naturais: Conceitos Básicos, Florianópolis-SC: Editora Organic Trading, 2006. 122 p. Disponível em:

<http://www.cetesb.sp.gov.br/userfiles/file/mudancasclimaticas/proclima/file/publicacoes/ada ptacao/portugues/prevencaodedesastresnaturaisconceitosbasicos.pdf. $>$. Acesso em novembro de 2018

LUIZ, E. L. Ocupação de Encostas: O caso do Bairro Saco Grande, Florianópolis - SC. Trabalho de conclusão de curso. Geografia Bacharelado. Universidade Federal de Santa Catarina, $1992.60 \mathrm{p}$.

LUIZ, E. L.; LAMAS, M. M. R. Aplicação do mapeamento geomorfológico na discussão das potencialidades e limitações de terrenos da zona costeira frente à ocupação humana: estudo de caso no Distrito de Rio Vermelho, Florianópolis/SC. SOCIEDADE \& NATUREZA (UFU. ONLINE), v. 29, p. 173-186, 2017.

MONTEIRO, M. A; MENDONÇA, M. Dinâmica atmosférica no estado de Santa Catarina. In: HERRMANN, M. L. P. Atlas de Desastres Naturais do Estado de Santa Catarina: período de 1980 a 2010. 2. ed. atual. e rev. Florianópolis: IHGSC/Cadernos Geográficos, 2014, p. 512.

NAÇÕES UNIDAS. ESTRATÉGIA INTERNACIONAL PARA LA REDUCCION DE DESASTRES (UN-ISDR). Terminología sobre Reducción del Riesgo de Desastres.

Ginebra, Suiza: UN, 2009. 39 p. 
PALACIOS, J. D.; CHUQUISENGO, O; FERRADAS, P. Gestión de riesgo em los gobiernos locales. Lima: Soluciones Prácticas- ITDG, 2005. 106 p.

SANTOS, L. A.; LUIZ, E. L. Áreas úmidas presentes nas diferentes formas de relevo do Distrito de Rio Vermelho - Florianópolis/SC. In: 25 Seminário de Iniciação Científica da Universidade do Estado de Santa Catarina, 2016, Florianópolis. Anais do 25ํㅗㄴ Seminário de Iniciação Científica da Universidade do Estado de Santa Catarina. Florianópolis: UDESC, 2016. p. 1-2.

TRICART, J. Ecodinâmica. Rio de Janeiro: FIBGE, Secretaria de Planejamento da Presidência da República, 1977. 97 p.

TRICART, J. Principes et méthodes de la Geomorphologie. Paris: Masson Ed., 1965. 496 p.

WHITE, G. F. Human adjustment to flood. University of Chicago, Department of Geography, Research Paper no. 29, 1945. 225 p.

\section{NOTAS DE AUTOR}

\section{CONTRIBUIÇÃO DE AUTORIA}

Edna Lindaura Luiz - Concepção, coleta de dados, análise de dados, elaboração do manuscrito, revisão e aprovação da versão final do trabalho.

Larissa Anjos Santos - Coleta de dados, participação ativa da discussão dos resultados, revisão e aprovação da versão final do trabalho.

João Paulo Oliveira da Rosa - Coleta de dados; participação ativa da discussão dos resultados.

\section{FINANCIAMENTO}

Não se aplica.

CONSENTIMENTO DE USO DE IMAGEM

Não se aplica

APROVAÇÃO DE COMITÊ DE ÉTICA EM PESQUISA

Não se aplica.

CONFLITO DE INTERESSES

Não há.

\section{LICENÇA DE USO}

Este artigo está licenciado sob a Licença Creative Commons CC-BY. Com essa licença você pode compartilhar, adaptar, criar para qualquer fim, desde que atribua a autoria da obra.

\section{HISTÓRICO}

Recebido em: 07-05-2018

Aprovado em: 14-12-2018 